\title{
Guru Menulis Itu Seksi ${ }^{1}$ \\ Oleh Teguh Trianton ${ }^{2}$
}

\begin{abstract}
"Tulisan adalah struktur visual dari isi pikiran. Demikian juga bahasa lisan, merupakan struktur dengaran dari isi pikiran. Keduanya juga dapat merepresentasikan kewarasan jiwa.”
\end{abstract}

[1]

Sesungguhnya menulis itu seksi. Seperti perempuan bagi laki-laki atau sebaliknya; aktivitas menulis juga dapat mengakibatkan kepayang, ektase, serta menimbulkan semacam ketagihan yang luar biasa. Menulis adalah aktivitas peribadatan intelektual yang produktif. Sedangkan tulisan merupakan struktur visual yang menjadi salah satu bukti. Menulis adalah salah satu bentuk latihan bagi kebugaran dan kesehatan otak. Tulisan merupakan postur atau wujud pikiran, gagasan buah dari kewarasan dan kesegaran otak.

"Organ tubuh perempuan (manusia) yang paling seksi adalah otak" (ini adalah pernyataan Dian Sastro Wardoyo, aktris Indonesia). Namun sayangnya bagian penting dari tubuh manusia ini jarang mendapat perhatian. Jarang mendapat nutrisi dan perawatan. Padahal untuk menjadi guru yang seksi, bugar, dan sehat tidak cukup hanya dengan melatih otot tubuh secara tertib.

Guru butuh menulis sebagai terapi agar lebih seksi. Seksi adalah sebuah kondisi yang dapat menstimulasi hasrat, membangkitkan minat, menimbulkan daya rasang, atau menimbulkan perhatian. Guru yang hanya dapat mengajar itu biasa. Ia tidak seksi. Guru yang mampu mengajar dan mempunyai tulisan (karya tulis) itu luar biasa. Ia sangat seksi.

Tulisan adalah candu. Ia dapat menyebabkan kita mencapai situasi ektase, mengalami pencerahan, pelepasan yang membuat kita sehat jasmani dan rohani. Tulisan merupakan salah satu sarana untuk meneguhkan identitas dan eksistensi diri.

Serupa candu, efek tulisan juga berkerja secara laten. Mula-mula kita akan merasa menikmati, ketagihan, selanjutnya ketergantungan. Namun untuk sampai pada situasi ketergantungan semacam itu bukanlah perkara mudah. Dibutuhkan kebiasaan mengonsumsi tulisan atau buku secara sehat dan teratur. Salah satu kecanduan yang wajib ditularkan adalah keanduan mengonsumsi bacaan.

Seperti obat; tulisan adalah racun yang berefek positif. Racun tulisan sama dengan racun pada obat, mesti diinjeksi sesuai resep atau aturan pakai agar tidak salah dosis dan lebih efektif. Sementara itu, menulis adalah proses injeksi nutrisi pada jiwa manusia. Jika tidak hati-hati, menulis dapat berakibat negatif. Oleh sebab itu, tulisan yang baik adalah tulisan yang memberikan efek positif pada pembaca -dan penulisnya-. Tulisan yang berbahaya adalah tulisan yang memberikan efek negatif baik bagi penulis maupun pembacanya.

Pada titik ini, kita hanya tinggal menentukan pilihan, caranya adalah dengan memahami etiket atau kaidah tulis menulis. Etiket tersebut secara sederhana memuat aturan mengenai; untuk siapa tulisan itu diramu, seperti apa kadar kandungannya. Lalu, bagaimana cara menyajikannya, dan apa efek samping yang bisa timbulnya.

\section{[3]}

Bagi para penulis professional, mencari ide dan menuliskannya menjadi karya (puisi, cerpen, esai, artikel, novel, dll.) merupakan kerja yang ringan. Kapan pun, di mana pun, mereka dengan leluasa dapat melakukan kerja menulis. Namun bagi pemula seperti saya, laku menulis -mulai mencari ide hingga menuangkan dalam bentuk karya- boleh jadi

\footnotetext{
${ }^{1}$ Esai ini disampaikan dalam acara Peluncuran dan Diskusi Buku karya Guru, dalam rangkaian kegiatan memperingati Hardiknas Tingkat Kabupaten Banjarnegara, 3 Mei 2018.

${ }^{2}$ Teguh Trianton adalah Penulis, Mantan Jurnalis, Kandidat Doktor Pendidikan Bahasa Indonesia UNS. Dia mengajar Kritik Sastra di Prodi PBSI FKIP Univeritas Muhammadiyah Purwokerto.
} 
membutuhkan ritual panjang yang melelahkan. Tak ayal, kita harus melewati tahap-tahap yang panjang, proses yang melelahkan untuk menciptakan sebuah karya sederhana.

Sesungguhnya ritual panjang yang melelahkan itu merupakan keniscayaan. Namun laku semacam itu tidak akan menjadi beban, tatkala literasi (aktivitas membaca dan menulis secara kritis) telah menjadi kebutuhan dan tradisi. Persoalannya adalah apakah literasi telah dimasukan dalam salah satu daftar kebutuhan primer hidup kita? Jangan-jangan, tradisi berliterasi di kalangan pendidik masih kalah jauh dari kebutuhan berswafoto, belanja produk kecantikan dan busana secara daring atau online, serta tradisi nonton.

Literasi bukanlah barang baru. Ia juga bukan merek industri atau label sosial milik kelompok tertentu. Bagi pendidik termasuk para guru, literasi sesungguhnya merupakan bagian dari aktivitas keseharian yang lazim. Oleh sebab itu, ia tidak perlu dirayakan. Kendati demikian, pemerintah telah mencanangkan Gerakan Literasi Sekolah (GLS) secara nasional. Gerakan ini agaknya digagas sebagai salah satu upaya menguatkan kembali atau memberi infus demi keberlangsungan kesehatan pendidikan kita. Lantaran pendidikan yang baik adalah yang dinamis, progresif, mengikuti perkembangan peradaban dan kebudayaan manusia.

Konsep literasi sudah bergerak dan berubah. Literasi bukan sekedar aktivitas membaca dan menulis atau keberaksaraan -sebagai penanda pergeseran dari budaya keberlisanan-. Literasi adalah seperangkat kompetensi untuk mengumpulkan, mengolah, dan menggunakan beragam informasi dari berbagai jenis - multi- teks untuk menjawab tantangan perubahan zaman dan memenuhi kebutuhan hidup manusia yang kompleks.

Oleh sebab itu, konsep literasi sudah tidak linier dengan sekadar aktivitas membaca dan menulis. Konsep literasi telah beralih menjadi aktivitas interpretasi teks secara bertingkat bahkan multiliterasi. Prosedur pemaknaan teks tidak lagi menghubungkan sistem tanda semuka tetapi antarmuka bahkan interktekstual dengan melibatkan banyak muka (multitasking).

Pada titik ini, untuk membuat sebuah tulisan yang baik, seorang penulis tidak mungkin berdiam diri atau hanya sibuk mengumpulkan bahan dari satu sumber. Demikian juga yang semestinya dilakukan oleh para penulis yang karyanya telah dicetak, diterbitkan, dan diluncurkan pada hari ini. Para penulis tentu saja telah melakoni dan melewati berbagai rintangan dalam proses panjang menulis buku.

[5]

\section{Membaca Jejak Literasi Guru}

Membaca buku adalah kerja keras menyelami gagasan penulis melalui proses identifikasi sistem tanda tingkat pertama (bahasa), menghubungkan dengan berbagai pengalaman estetik pembaca untuk menemukan interpretasi yang paling kontekstual. Prosedur ini dapat ditempuh dengan melakukan dialog antara pengetahuan penulis dengan pengetahuan pembaca. Dengan demikian, membaca merupakan proses mengisi teks dengan konteks sehingga melahirkan makna yang tidak pernah final.

Membaca buku adalah aktivitas intelektual yang melibatkan berbagai teks yang melatari pengalaman pembaca untuk membongkar berbagai kemungkinan pesan dari penulis. Seorang pembaca acap kali dihadapkan pada situasi yang tidak netral. Ia tidak mungkin datang dalam kondisi bersih dari berbagai kecurigaan terhadap teks yang akan dibacanya. Interpretasi terhadap teks yang dibaca sesungguhnya merupakan proses menarasikan ulang isi bacaan sesuai pengalaman estetik pembaca. Saya pun, demikian. Tatkala menghadapi buku, semua pembaca adalah pembaca yang tidak bersih. Alih-alih melakukan interpretasi secara presisi dan bersih, sebenarya adalah menanamkan kecurigaan dan menceritakan ulang. 
Membaca dan menulis adalah dua aktivitas produktif yang melibatkan berbagai unsur kebudayaan secara simultan. Itulah sebabnya, karya tulis atau buku selalu merepresentasikan pengalaman, perasaan, pandangan hidup, bahkan ideologi seorang penulis sesuai latar budayanya.

Buku bertajuk Koper Packer, misalnya. Buku karya Wahyuning Widhiati ini secara tegas ditulis sebagai upaya berbagi pengalaman penulis dalam mengelola Program Literasi Sekolah untuk menumbuhkan minat membaca di SMP Negeri 2 Banjarnegara. Buku dengan tebal 60 halaman ini juga menyajikan narasi-narasi pendek tentang pengalaman penulis sebagai seorang guru. Buku ini dibagi dalam dua bagian. Pada bagian kedua, penulis mengisahkan pandangannya mengenai berbagai persoalan keseharian dari perspektif ibu rumah tangga.

Bagian pertama diberi judul 'Kepakan Sayapmu' yang berisi tujuh tulisan ringkas mengenai pernak-pernik mengelola ruang budaya literasi di sekolah. Ada empat tulisan yang secara lugas diberi label yang sama secara berseri yaitu "Bianglala Literasi Di Sekolahku". Meski demikian, tiga tulisan lainnya sesungguhnya memiliki nafas yang senada. Bagian pertama ini menyuguhkan pengalaman penulis sekaligus niatan memberi motivasi pada pembaca dalam menumbuhkan budaya literasi.

Bagian kedua buku ini bertajuk 'Saya Perempuan Biasa'. Bagian ini berisi sepuluh tulisan, empat tulisan merupakan tulisan serial berjudul 'Koper Packer'. Tulisan-tulisan ini juga merupakan narasi pendek yang berisi berbagai kiat melakukan perjalan wisata bersama keluarga. Artikel-artikel pendek ini sesungguhnya akan lebih menarik jika dibuat menjadi satu buku utuh berisi kisah pengalaman perjalanan wisata (traveling). Penulis dapat memperluas cakrawala tulisan dengan menambahkan lebih detail berbagai nilai (value) dan isi (content) penting dari aktivitas perjalan wisata tersebut.

Secara umum penulis mempresentasikan seluruh pengalaman dan pandangannya dengan gaya memoar. Inilah barangkali gaya sengaja dipilih. Meski demikian, narasi yang dibangun menjadi agak kaku dengan munculnya banyak penomoran. Kesan pertama terhadap buku ini sebagai buku cerita sedikit berkurang dan nyaris beralih menjadi buku kiat-kiat atau semacam best practies. Tentu saja munculnya penomoran di banyak bagian pada buku ini bukan tanpa alasan. Boleh jadi penulis ingin menjelaskan secara kronologi setiap peristiwa atau langkah yang harus dilakukan dalam menyelesaikan persoalan.

Menulis yang paling sederhana adalah menulis pengalaman hidup sendiri. Aforisme ini agaknya dipilih sebagai mantra dalam tonggak kepenulisan Supono. Guru yang juga Kepala SMP Negeri 3 Wanayasa ini meracik sepuluh kisah religius menjadi buku setebal 84 halaman. Judul buku sangat sederhana. Penulis memilih salah satu judul cerita primordialnya menjadi judul buku: Rezeki Tak Akan Tertukar. Pada bagian isi buku, judul ini ditulis dengan variasi tanda kurung pada frase 'Tak Akan' sehingga menjadi 'Rezeki (Tak Akan) Tertukar'. Boleh jadi penulis berniat bermain tebak-tebakan isi cerita dengan meciptakan ambiguitas melalui judul, meskipun sebenarnya tidak perlu.

Judul cerita tersebut sesungguhnya terlalu populer atau biasa. Seorang pembaca dapat dengan mudah menebak isi ceritanya. Karakteristik judul yang sangat sederhana ini juga melekat pada seluruh cerita yang ada dalam buku. Judul yang lain di antaranya adalah; 'Nyadran', '(Dikira) Allah Lupa', 'Ujungan', dan 'Doa Untuk Banjarnegara'.

Sebagai sebuah teks yang ditulis secara primordial dengan merujuk pada nilai-nilai kerohanian, buku ini tentu saja sarat dengan pesan moral yang lugas. Sebenarnya melalui gaya berkisah, penulis berupaya sedikit menyamarkan petuah yang ingin disampaikan. Namun upaya ini belum sepenuhnya berhasil, lantaran isi cerita begitu mudah diteroka. Ramuan kisah yang ditulis untuk mengemas pesan dari kitab suci sangat kentara. Akibatnya narasi-narasi yang ditampilkan cenderung banal. Boleh jadi penulis memang sengaja melakukan ini, lantaran buku ini sepertinya didedikasikan untuk pembaca remaja. 
Salah satu ciri teks yang bersifat primordial adalah ia memiliki referensi budaya yang eksklusif. Teks seperti ini selalu menyimpan tanda dalam relasi intertekstual yang tertutup. Sifat eksklusif pada teks semacam ini juga selalu melekat pada kisah-kisah asal-asul sebuah tempat atau legenda.

Sebagai kisah sejarah yang berasal dari cerita rakyat (floklor), cerita legenda agak sulit dikembangkan. Meski demikian banyak penulis yang berani memberi perspektif baru terhadap sejumlah legenda. Sehingga, hubungan intertekstual antara cerita lisan sebagai hipogram dengan cerita turunannya menjadi kreatif. Seorang penulis dapat melakukan tranformasi bahkan dekonstruksi terhadap teks pertama.

Namun, pola ini tidak tampak pada cerita Legenda Terjadinya Desa Gumelem gubahan penulis Winarti Peni Subekti. Kisah asal-usul terjadinya desa tersebut dibagi menjadi 14 kisah berseri. Seperti cerita legenda pada umumnya, narasi-narasi dalam buku cerita ini juga berfokus pada tokoh-tokoh sebagai pelaku peristiwa. Penggunaan sudut pandang orang ketiga membuat cerita ini cukup berjarak dengan penulisnya. Namun demikian, membaca cerita dalam buku ini seperti memasuki cerita klasik yang ringan dan mudah dicerna. Penempatan dialog-dialog ringkas antartokoh dalam cerita, memudahkan pembaca mengidentifikasi pesan yang ingin disampaikan.

Salah satu unsur yang menjadi daya tarik dari sebuah cerita legenda adalah deskripsi latar yang detail. Namun kesan ini belum dimunculkan secara rinci dan elok dalam cerita tersebut. Pembaca kurang mendapatkan visualisasi verbal dari setiap latar yang ada dalam legenda. Kendati demikian, penulis telah berhasil melakukan upayanya mengawetkan ingatan sejarah mengenai kearifan lokal yang sudah lama terlupakan.

Menulis cerita legenda adalah mengemas silsilah dalam struktur bahasa yang terbuka. Menulis legenda setali tiga uang dengan menulis sejarah. Oleh karena itu, cerita legenda yang baik dapat didukung dengan data-data dari sumber yang terpercaya. Meski legenda sejatinya adalah cerita rakyat, namun ia tidak hadir semata-mata sebagai sebuah cerita. Legenda selalu mengandung nilai kearifan budaya tempatan. Inilah yang mestinya menjadi perhatian untuk ditulis ulang.

Setiap tulisan pada dasarnya lahir sebagai representasi dari pengalaman hidup penulisnya. Tulisan merupakan rekam jejak intelektual yang bersifat abadi. Melalui tulisan, seseorang dapat diidentifikasi, dikenali secara personal. Tulisan dapat mencerminkan isi pikiran, sekaligus bacaan yang dikonsumsinya. Semakin banyak membaca maka akan semakin memperkaya tulisan. Itulah sebabnya syarat pertama yang wajib dipenuhi oleh seorang yang ingin menjadi penulis yang baik adalah dengan menjadi pembaca yang baik terlebih dahulu.

Syarat ini agaknya belum cukup terpenuhi, atau belum cukup tercermin pada buku kumpulan puisi berjudul Puisi Sejuta Rasa yang dianggit oleh Sutini, Guru SMP Negeri 1 Karangkobar, Banjarnegara. Buku puisi ini memuat sekitar 41 puisi dengan beragam tema dalam satu corak gaya estetik yang cenderung membosankan.

Agaknya penulis masih kurang mengeksplorasi estetika pengucapan puisinya. Sehingga seluruh puisi dipresentasikan dengan cara yang sama, monoton, dan beku. Boleh jadi, penulis sengaja memilih cara ini bukan lantaran ketidaktahuannya mengenai bentuk dan komposisi puisi terkini. Kesengajaan ini sepertinya dipilih sebagai ciri khas atau gaya ungkap yang sederhana.

Tetapi dalam konteks wacana perpuisian modern, gaya menulis puisi dengan tipografi yang menonjolkan lekuk tubuh puisi melalui perpindahan bait sudah tidak lazim. Pembaca tidak menemukan hubungan atau konteks antara isi puisi dengan bentuk yang berlekuk seperti itu. Tipografi sesungguhnya merupakan salah satu elemen yang lazim digunakan penyair untuk memberikan sugesti pada pembaca mengenai isi pesan dalam puisi. Tipografi 
dibangun dengan konsep yang jelas dan memiliki relevansi dengan keutuhan puisi. Ia dibangun tidak semata-mata hanya sebagai ornamen.

Dalam konteks ini, aku lirik sepertinya belum berhasil mendayagunakan tipografi sebagai instrumen penting untuk turut mendesakkan pesan dalam setiap komposisi puisi yang ditulisnya. Meski demikian, penulis telah berupaya memasukan beragam tema dalam puisipuisinya. Aku lirik sesungguhnya tengah mencurahkan segala perasaan di hatinya sebagai seorang guru, ibu rumah tangga, sekaligus istri untuk sang suami. Curahan hati itu ditulis dengan komposisi yang dibuat pendek-pendek dan berbait menyerupai puisi klasik. Diksi yang digunakan sangat sederhana, sehingga memudahkan proses interpretasi. Komposisi ungkapan tidak njelimet, sehingga menghilangkan kesan bahwa puisi adalah komposisi yang rumit.

Gaya dan daya ungkap puisi yang relatif lebih kekinian tampak dalam kumpulan sajak berjudul Jantung Ungu karya Yusianti. Penulis yang juga guru Bimbingan Konseling (BK) SMP Negeri 2 Banjarnegara ini tidak punya persoalan dengan tipografi. Agaknya, sebagai penulis, ia cukup sadar dengan pilihan genre tulisannya. Yusi menyadari, cukup menyadari bahwa kekuatan puisi tidak bertumpu pada tipografi, melainkan pada komposisi ungkapan yang dibangun dari diksi.

Terdapat sekitar 54 komposisi yang berbicara mengenai cinta, rindu, kasih sayang, cemburu dan paket perasaan lain yang dekat dengan perkara hati. Cinta merupakan tema yang tidak pernah kering untuk ditulis. Ia memliki dimensi yang nirwatas. Cinta juga menjadi tema pertama yang paling lazim dipilih oleh para penulis pemula. Bahkan perkara cinta jarang sekali absen dari setiap karya sastra. Jika cinta tidak menjadi tumpuan kisah, maka ia menjadi kisah itu sendiri.

Pemilihan cinta baik sebagai tumpuan kisah maupun sebagai kisah itu sendiri sebenarnya dapat menjebak penulis pada repitisi ungkapan dan diksi. Persoalan ini akan mengantarkan penyair terlena pada diksi yang puitis, sehingga melupakan upaya mencari kebaruan pengucapan dan mengisi bangunan puisi dengan nilai-nilai tertentu. Inilah impresi awal yang tumbuh saat pertama saya melakukan pembacaan puisi dalam buku tersebut.

\section{[6]}

\section{Berguru pada Ahmad Tohari}

Nama Ahmad Tohari mulai melambung pada dekade 1970-an. Cerpen berjudul Jasajasa Buat Sanwirya pada tahun 1975 mendapat anugerah Sayembara Kincir Emas Radio Nederland Wereldomroep. Kemudian, tahun 1989, cerpen ini, dibukukan bersama 12 cerpen lain dalam buku kumpulan cerpen Senyum Karyamin. Ia mendapat Hadiah dari Yayasan Buku Utama untuk novel Kubah (1980), Hadiah Sayembara Penulisan Roman Dewan Kesenian Jakarta (DKJ) untuk novel Di Kaki Bukit Cibalak (1986). Pada tahun 1990, ia mengikuti International Writing Programme di Amerika Serikat. AT memperoleh penghargaan Fellow Writer the University of Iowa. Pada tahun 1995 ia mendapat Penghargaan Bhakti Upapradana dari Pemerintah Provinsi Jawa Tengah untuk Pengembangan Seni Budaya dan South East Asia Writes Award, di Bangkok.

Terkini, karya-karya Ahmad Tohari banyak diterjemahkan ke dalam berbagai bahasa di dunia. Pada Tahun 2016, sastrawan yang juga kiyai dan budayawan Banyumas ini mendapat penghargaan penulis cerpen terbaik Kompas 2015. Produktifitasnya sangat mengesankan. Di usia 68 tahun, Kiyai Tohari masih produktif berkarya. Ini terbukti dengan terbitnya buku kumpulan cerpen teranyar bertajuk Tawa Gadis Padang Sampah (2017), yang memuat tujuh cerpen terbarunya.

Karakteristik kepenulisan Ahmad Tohari adalah kesetiaanya pada persoalan orangorang kecil, penduduk desa, rakyat jelata yang hidup apa adanya, sederhana dan cenderung 
marginal serta yang tinggal di pinggiran. Dalam konteks daya ungkap, Ahmad Tohari berhasil meramu diksi dari bahasa lokal yang bernuansa kedaerahan dari bahasa ibu dengan kata-kata dalam bahasa Indonesia sebagai bahasa resmi negara.

Ciri lain yang melekat pada karya Ahmad Tohari adalah kepiawaiannya dalam membangun deskripsi latar yang detail dan presisi. Sehingga, pembaca mampu membangun imajinasinya secara kukuh dan pasti mengenai berbagai peristiwa yang dikisahkan. Kemampuannya yang mumpuni dalam mengemas pesan melalui komposisi tuturan yang ringkas dan terang, membuat pembaca dapat dengan mudah dan tertib merenungi maksud yang disampaikan.

Salah satunya tampak pada cerpen berjudul Gulai Kham-bing dan Ibu Rapilus. Cerpen ini berkisah tentang dua orang sahabat lama yang bertemu di sebuah warung gulai. Jubaedi, tokoh utama dalam cerpen ini bertemu dengan tokoh aku yang bertindak sebagai narator. Keduanya merupakan sahabat yang pernah belajar dalam satu sekolah yang sama.

Topik yang diangkat sangat sederhana yaitu tentang bagaimana cara mengingatkan orang lain mengenai pentingnya kehati-hatian dan ketelitian yang akan beujung pada sebuah kebenaran. Ahmad Tohari sebenarnya tengah mengingatkan pembaca mengenai perkara tersebut. Dia hanya meminjam nama untuk beberapa tokoh rekaan dari bank kreativitasnya.

Melalui dialog Jubedi dengan tokoh aku yang sesekali ditingkahi oleh ibu pemilik warung, Tohari berusaha membangun latar suasana, latar sejarah, latar budaya, dan latar intelektual para tokoh. Konstruksi latar ini pada gilirannya disusun menjadi sebuah plot yang efektif menimbulkan kejutan-kejutan.

Melalui tokoh Jubedi, pengarang hendak menggambarkan karakter manusia Indonesia yang mudah terlena, kurang awas dan mawas. Jubedi digambarkan terlena dengan kenikmatan gulai, sehingga dia kehilangan pengetahuaan, keawasan, dan kejelian indranya. Gulai yang ia makan sesungguhnya adalah gualai anjing yang dilafalkan 'Kham-bing' oleh ibu pejual di warung.

Ketengangan muncul justru pada tokoh aku yang berupaya secerdas mungkin memberitahu mengenai kenyataan tersebut. Dia mencoba mengingatkan Jubedi mengenai ciri-ciri pembeda antara binatang carnivora dan herbivora; antara anjing dan kambing. Jubedi dibawa mengingat kembali masa belajar di SMP melalui tokoh Ibu Rapilus, guru biologi yang menerangkan perbedaan tersebut.

Tetapi upaya tokoh aku gagal. Akhirnya Jubedi pergi meninggalkan warung dengan perut penuh daging dan tulang anjing yang disantapnya dalam menu gulai. Sementara tokoh aku memilih membawa pulang gulai pemberian yang dibelikan sahabatnya itu. Ia meminta ibu penjaga warung membungkus gulai. Lalu ia membawanya pulang. Di tengah perjalan ia berikan gulai anjing itu pada seekor anjing di tepi jalan.

Sesungguhnya pengarang tidak peduli dengan nasib Jubedi. Tokoh ini hanya dipinjam untuk mengemas pesan yang sebenarnya ditujukan pada pembaca. Pengarang juga tidak memedulikan ekspektasi pembaca mengenai akhir cerita yang mungkin diharapkan. Jubedi tetap dengan kebodohannya, terlena dengan kenikmatan makanan, sehingga lupa dengan apa yang sebenarnya dia makan. Tetapi amanat atau nasehat yang dibawa telah sampai dan dipahami oleh pembaca. Lantaran pembacalah yang sesungguhnya tengah diberi nasehat tersebut.

Dari beberapa karakteristik kepenulisan Ahmad Tohari tersebut, setidaknya kita dapat belajar bahwa (a) menulis karya sastra tidak harus memilih tema yang rumit, (b) komposisi ungkapan dibangun dengan diski yang selaras dengan tema dan pesan, (c) deskripsi merupakan salah satu alat yang ampuh untuk merangsang imajinasi pembaca, dan (d) pesan moral dapat dikemas dengan konstruksi tuturan yang ringkas tetapi estetik. 